\title{
Mesenchymal Stem Cell-Mediated Effects of Tumor Support or Suppression
}

\author{
Ki-Jong Rhee ${ }^{1,+}$, Jong In Lee ${ }^{2, \dagger}$ and Young Woo Eom ${ }^{3, *}$ \\ Received: 23 September 2015; Accepted: 1 December 2015; Published: 16 December 2015 \\ Academic Editor: William Chi-shing Cho \\ 1 Department of Biomedical Laboratory Science, College of Health Sciences, Yonsei University, 1 Yonseidae-gil, \\ Wonju 26493, Korea; kjrhee@yonsei.ac.kr \\ 2 Department of Hematology-Oncology, Wonju College of Medicine, Yonsei University, 20 Ilsan-ro, \\ Wonju 26426, Korea; oncohem@yonsei.ac.kr \\ 3 Cell Therapy and Tissue Engineering Center, Wonju College of Medicine, Yonsei University, 20 Ilsan-ro, \\ Wonju 26426, Korea \\ * Correspondence: yweom@yonsei.ac.kr; Tel.: +82-33-741-0260; Fax: +82-33-743-0411 \\ + These authors contributed equally to this work.
}

\begin{abstract}
Mesenchymal stem cells (MSCs) can exhibit a marked tropism towards site of tumors. Many studies have reported that tumor progression and metastasis increase by MSCs. In contrast, other studies have shown that MSCs suppress growth of tumors. MSCs contribute to tumor growth promotion by several mechanisms: (1) transition to tumor-associated fibroblasts; (2) suppression of immune response; (3) promotion of angiogenesis; (4) stimulation of epithelial-mesenchymal transition (EMT); (5) contribution to the tumor microenvironment; (6) inhibition of tumor cell apoptosis; and (7) promotion of tumor metastasis. In contrast to the tumor-promoting properties, MSCs inhibit tumor growth by increasing inflammatory infiltration, inhibiting angiogenesis, suppressing Wnt signaling and AKT signaling, and inducing cell cycle arrest and apoptosis. In this review, we will discuss potential mechanisms by which MSC mediates tumor support or suppression and then the possible tumor-specific therapeutic strategies using MSCs as delivery vehicles, based on their homing potential to tumors.
\end{abstract}

Keywords: mesenchymal stem cells; tumor microenvironment; homing; delivery vehicles

\section{Introduction}

Mesenchymal stem cells (MSCs) are a promising source for cell therapy in regenerative medicine. The therapeutic properties of MSCs are related to their potentials for trans-differentiation, immunomodulation, and trophic factor secretion. The minimal criteria for human MSCs were defined by the International Society for Cellular Therapy, in 2006, as follows: (1) MSCs must be plastic-adherent when maintained under standard culture conditions; (2) more than $95 \%$ of cells in a given population of MSCs should express CD105, CD73, and CD90, and lack the expression (less than $2 \%$ positive) of CD 45, CD34, CD14 or CD11b, CD79 $\alpha$ or CD19, and HLA class II surface molecules; (3) MSCs must differentiate into osteoblasts, adipocytes, and chondroblasts under standard conditions in vitro [1]. Investigators have isolated MSCs from many different tissues, including bone marrow, adipose tissue, umbilical cord blood, peripheral blood, dermis, liver, skin, and skeletal muscle [2-7]. In many studies it has been reported that MSCs that originated in different tissues have similar properties (i.e., expression of cell surface antigens, immunomodulatory capability, and tropism towards tumor) [8,9]. By contrast, it has been reported that different MSCs isolated from two distinct tissues can be recruited into tumor microenvironments, and the different MSC types can be more prompt to transdifferentiate into determined cell types [10]. The different types of MSCs express a distinct 
set of genes, which is a reflection of its differentiation potential and origin [11,12]. MSCs can be expanded without the loss of their potential for use in clinical applications or differentiation into multiple cell lineages, including adipocytes, osteocytes, chondrocytes, hepatocytes, fibroblasts, and pericytes [13-17]. However, the trans-differentiation of MSCs has rarely been observed in animal models [18]. MSCs can secrete various immunomodulators, such as nitric oxide (NO), prostaglandin (PGE2), indoleamine 2,3-dioxygenase (IDO), interleukin (IL)-6, IL-10, and HLA-G. These soluble factors modulate the function of various immune cells as well as induce $T$ regulatory cells (reviewed in [19]). In addition to the release of immunomodulators, MSCs can directly suppress immune cell activation via cell-to-cell. T cell proliferation can also by inhibited by MSC by inducing effector T cell apoptosis through interaction of programmed death-1 (PD-1) molecules with its cognate ligands PD-L1 and PD-L2. Furthermore, MSCs can induce T cell anergy by downregulating expression of CD80 and CD86 on antigen-presenting cells [20-22]. In addition, MSCs secrete various modulatory factors that can regulate inflammation, cell death, angiogenesis, fibrosis, and tissue regeneration [23]. It has been reported that MSCs secrete trophic factors that promote cell survival (SDF-1, HGF, IGF-1), cell proliferation (EGF, HGF, NGF, TGF- $\alpha$ ), and tissue angiogenesis (VEGF) [24-26]. Moreover, MSCs can migrate toward injury sites along chemoattractant gradients in the stromal extracellular matrix (ECM) and peripheral blood [27]. In injury sites, MSCs are stimulated by local factors, such as hypoxia, cytokine milieu, and Toll-like receptors ligands. This diverse array of stimuli promotes formation of abundant growth factors that converge to augment tissue regeneration $[28,29]$.

In contrast to the usage of MSCs in regenerative medicine, recent data suggest that MSCs can either augment tumorigenesis or inhibit tumorigenesis [30,31]. In the tumor microenvironment, the tumor attempts to avoid recognition by the immune system while simultaneously secreting inflammatory mediators to establish and maintain a constant state of inflammation [32]. Moreover, the correlation between normal cells, cancer cells, and the matrix within the tumor microenvironments has gained increasing attention, especially because these interactions contribute to certain milestones of cancer, such as immunomodulation, angiogenesis, invasion and metastasis, and apoptotic resistance [33,34]. In several studies, it has been shown that MSCs migrate to the tumor microenvironment and then subsequently support formation of tumor vasculature, enhance the fibrovascular network, and suppress immune reactions, thereby modulating the tumor response to anti-tumor therapy (reviewed in [35-39]). In contrast to their tumor-promoting abilities, MSCs can also suppress tumor growth via inhibition of proliferation-related signaling pathways such as AKT, PI3K, and Wnt, inhibition of cell cycle progression, downregulation of XIAP (X-linked inhibitor of apoptosis protein), and suppression of angiogenesis [40-47].

In this review, we have summarized the mechanisms of MSC-mediated effects of tumor support or suppression and then discussed possible tumor-specific therapeutic strategies using MSCs as delivery vehicles, based on their homing potential to tumors.

\section{Promotion of Tumor Growth by MSCs}

The tumor microenvironment, which is composed of cancerous cells, non-cancerous cells, and their stroma, influences cancer growth [48]. The tumor stroma harbors many cell types as well as the extracellular matrix. These cells include different kinds of immune cells, fibroblasts, endothelial cells, and myofibroblasts [49]. MSCs move to tumor sites and then incorporate into the tumor stroma [50,51]. These cells interact with each other and with cancer cells, resulting in the promotion of tumor growth. The ability of MSCs to promote tumor growth and metastasis was proved in a breast tumor mouse model [52] and similar results were also obtained from cancer cells co-implanted with MSCs [53-55]. Furthermore, allogeneic mice transplanted with B16 melanoma cells did not support tumor formation in the absence of concomitant MSC co-injection [56]. This finding indicates that MSCs exert immunosuppressive effects that were required for tumor initiation. In this review, we will elaborate on how MSCs contribute to tumorigenesis, including (1) by transition to tumor-associated fibroblasts; (2) by suppression of the immune response; (3) by promotion of angiogenesis; (4) by 
stimulation of epithelial-mesenchymal transition (EMT); (5) through contribution to the tumor microenvironment; (6) by inhibition of tumor cell apoptosis; and (7) by promotion of tumor metastasis (Figure 1).

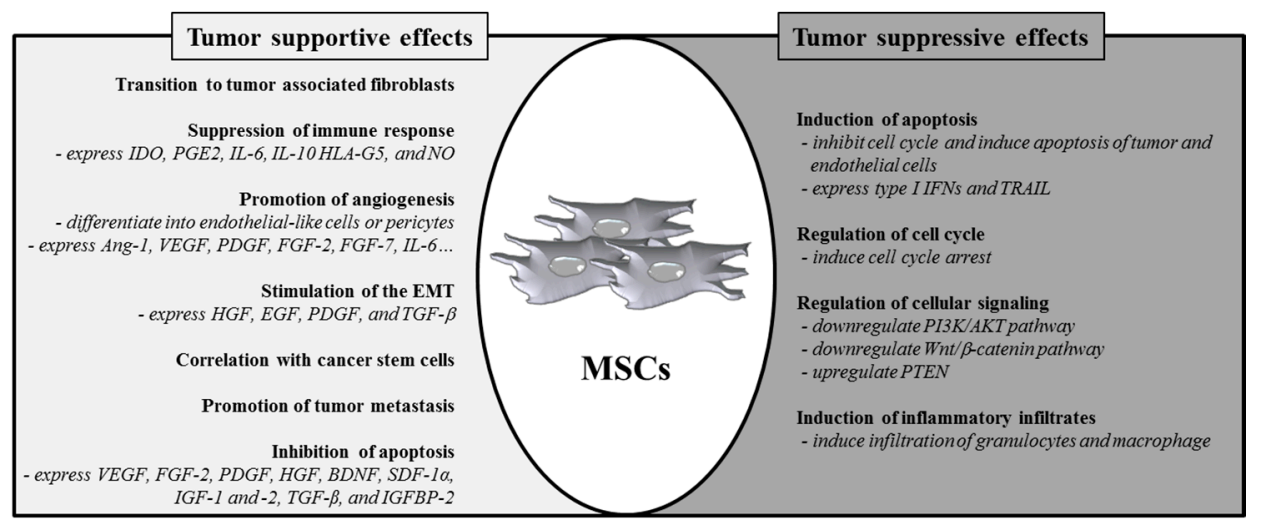

Figure 1. Role of MSCs in tumor formation or suppression. MSCs can regulate transition to tumor-associated fibroblasts, immune response, angiogenesis, EMT, cancer stem cells, metastasis, and apoptosis. Alternatively, growing evidence shows that MSCs inhibit tumor cell function by inducing apoptosis, cell cycle arrest, and inflammatory infiltration and inhibiting the Wnt and AKT signaling pathways.

\subsection{Transition of Mesenchymal Stem Cells to Tumor-Associated Fibroblasts}

Tumors consist of cancerous cells and different stromal cells that form the tumor cellular milieu [34,57]. The tumor stroma consists of an extracellular matrix (ECM) scaffold populated by stromal cells including fibroblasts, immune cells, and endothelial cells. Fibroblasts can be activated in the tumor stroma and activated fibroblasts (also designated myofibroblasts) are called carcinoma-associated fibroblasts (CAFs) or tumor-associated fibroblasts (TAFs). CAFs/TAFs are abundant in most invasive tumors and are composed mainly of cells expressing $\alpha$-smooth muscle actin ( $\alpha$-SMA) [58]. These cells promote tumor growth and angiogenesis via secretion of stromal-cell derived factor 1 (SDF-1) [59], which binds to CXCR4 expressed by tumor cells [60]. Recently, it was reported that MSCs can differentiate into CAFs/TAFs [37,55,61,62]. Indeed, MSCs can differentiate into myofibroblasts with concomitant increased production of $\alpha$-SMA, tenascin-C and fibroblast surface protein (FSP), CCL5/RANTES, and SDF-1 [37,61-63]. Therefore, the CAFs/TAFs differentiated from MSCs can stimulate tumor growth via the contribution of angiogenesis and the production of tumor-stimulating growth factors.

\subsection{Suppression of Immune Response in Tumor Microenvironments}

In addition to protecting the host against foreign invaders, the immune system recognizes tumor antigens and eliminates malignant tumors [64,65]. Therefore, tumor growth, invasion, and metastasis are important aspects of the tumor immune escape mechanism. During tumor initiation, tumor-associated macrophages (TAMs) and MSCs migrate into tumor microenvironments. TAMs act as the major inflammatory component of the tumor microenvironment [66-68] and consist of M1 phenotype cells, which kill pathogens, and M2 phenotype cells, which induce angiogenesis and tissue remodeling [69-71]. M2 macrophages can support tumor growth by secreting EGF, PDGF, FGF, VEGF, TGF- $\beta$, IL-4, and IL-13 [69,70,72-76]. In contrast, TAMs can show antitumor activities linked to the M1 phenotype via IFN- $\gamma$, TNF- $\alpha$, TGF- $\beta$, PGE2, and IL-10 [72,77-82]. In addition, M1 TAMs produce oxygen radicals, nitrogen radicals, and pro-inflammatory factors (e.g., IL-1 $\beta$, IL-6, IL-12, IL-23, and TNF- $\beta$ ) that can facilitate the killing of cancer cells. 
In tumor microenvironments, MSCs can be activated by pro-inflammatory cytokines IFN- $\gamma$, TNF- $\alpha$, or IL-1 $\beta[52,69,83-85]$, which are secreted by tumor cells and macrophages and then produce immunomodulatory molecules, such as IDO, PGE2, IL-6, IL-10, HLA-G5, and nitric oxide (NO) (reviewed in [86]). IDO is the critical rate-limiting enzyme of tryptophan catabolism through the kynurenine pathway, resulting in tryptophan depletion and halting the growth of various cells. Since both IDO and HLA-G are expressed in the placenta, these molecules likely play a role in immune tolerance during pregnancy. Moreover, IDO and HLA-G inhibit effector T cell proliferation, DC maturation, B cell proliferation, IgG secretion, and nature killer (NK) cell activity [87,88]. PGE2 has a multifunctional role in pathological processes and regulates inflammation and cancer. Production of PGE2 by MSCs is increased following TNF- $\alpha$ or IFN- $\gamma$ stimulation. Furthermore, PGE2 increases the expression level of anti-inflammatory cytokine IL-10 and decreases expression of TNF- $\alpha$, IFN- $\gamma$, and IL-12 in dendritic cells (DCs) and macrophages [89,90]. PGE2 also dampens secretion of IFN- $\gamma$ and IL-4 in Th1 and Th2 cells, respectively, and promotes proliferation of Treg cells [19]. MSC-secreted IL-6 inhibited monocyte differentiation toward DCs and subsequently induced a decrease in the stimulatory ability of DCs on T cells [91,92]. In addition, IL-6 secreted by MSCs resulted in the delay of apoptosis of lymphocytes and neutrophils $[93,94]$. NO is produced by inducible NO synthase (iNOS) via stimulation by inflammatory factors such as IL- 1, IFN- $\gamma$, and TNF- $\alpha[95,96]$ and also inhibits the functions of T cells [97].

\subsection{Promotion of Angiogenesis}

Blood vessels supply the tumor with nutrients and oxygen, resulting in tumor growth and increased tumor metastasis. Various studies have suggested that MSCs promote tumor angiogenesis through their potential to differentiate into endothelial-like cells or pericytes as well as by their secretion of trophic factors and proangiogenic factors, growth factors, cytokines, and plasminogen activator $[55,98,99]$. These molecules induce angiogenesis of endothelial cells synergistically [100]. VEGF and FGF-2 are two key vasculogenic factors secreted by MSCs that promote tumor neovascularization [55]. Mobilization and recruitment of MSCs into neovascularization sites can be increased by VEGF expression and then MSCs can be directly differentiated into vascular cells [30,101]. Moreover, VEGF expression by MSCs can be increased by hypoxic conditions, which are common in tumor tissues [102]. In addition, MSCs enhanced blood vessel integrity by inducing expressing of junctional proteins [103]. MSCs also directly increase the angiogenic process as endothelial cells, smooth muscle cells, or pericytes [104]. Rat MSCs that had been incorporated into tumor vessel walls did not express endothelial markers but did express several pericyte markers such as NG2, $\alpha$-SMA, and PDGFR- $\beta$ [99]. Taken together, the distinct pericyte marker expression profile of the engrafted MSC as well as the perivascular location suggest that these cells function as pericytes. Additionally, human MSCs co-incubated with conditioned media from a glioblastoma expressed several markers characteristic of pericyte differentiation $[105,106]$.

\subsection{Epithelial-Mesenchymal Transition (EMT)}

Epithelial-mesenchymal transition (EMT) is characterized by downregulation of epithelial cell-associated proteins E-cadherin, $\gamma$-catenin/plakoglobin, and ZO-1. In contrast, there is an upregulation of mesenchymal proteins, including $\mathrm{N}$-cadherin, vimentin, fibronectin, and smooth muscle actin $[107,108]$. While EMT is required for organogenesis and wound healing, epithelial tumor development is also associated with EMT [109]. Accumulating evidence suggests that aberrant EMT promotes tumor invasiveness, tumor metastasis, and drug resistance [110]. In many tumors, molecules such as HGF, EGF, PDGF, and TGF- $\beta$ are produced from the tumor-associated stroma and act as EMT-inducing signals [109,111,112]. Interestingly, these factors are secreted by MSCs [29] and activate a series of EMT-promoting transcription factors such as Snail, Slug, zinc finger E-box binding homeobox 1, and TWIST [113,114] to transmit EMT-promoting signals [115]. Experimental evidence from a recent study showed that upregulation of EMT-specific genes followed co-culture of breast 
cancer cells with MSCs expressing decreased levels of an epithelial-specific gene [116]. MSCs also enhanced the metastatic capacity of colon cancer cells with an elevated expression of EMT-associated genes, such as ZEB1, ZEB2, Slug, Snail, and Twist, in a contact-dependent manner. Of note, the EMT-related gene E-cadherin was significantly downregulated [117]. Leptin produced by MSCs enhanced expression of EMT and metastasis genes (SERPINE1, MMP-2, and IL-6) in breast cancer cells. In addition, when SCID/beige mice were co-injected with MCF7 breast cancer cells with MSCs containing leptin shRNA, leptin levels in MSCs decreased and also caused a reduction in MCF7 tumor volume and fewer metastatic lesions in the lungs and livers of mice [118]. Moreover, MSCs can fuse with different cancer cells and show all the classical characteristics of EMT [119-124].

\subsection{Correlation of MSCs with Cancer Stem Cells}

Cancer stem cells (CSCs) have been identified in recent years in a variety of solid tumors [125]. There is increasing evidence that these CSCs mediate tumor metastasis and may contribute to relapse following chemotherapy and radiation therapy [126]. Liu et al. showed that breast populations of both CSCs and MSCs form a cellular hierarchy in which MSCs expressing aldehyde dehydrogenase regulate breast CSCs through signaling pathways involving IL-6 and CXCL 7 [127]. IL-6 produced by CSCs interacts with IL-6R/gp130 expressed on MSCs, followed by production of CXCL7 by MSCs [127]. In turn, CXCL7 induces the secretion of a number of cytokines from both CSCs and MSCs, including IL-6, IL-8, CXCL6, and CXCL5 [127]. It has been shown that these cytokines trigger proliferation of CSCs and enhance their invasive properties, whereas IL-6 mediates chemotaxis, which promotes MSCs homing to primary tumor growth sites in mouse xenograft models [52,127]. Carcinoma-associated MSCs (CA-MSCs) express BMP2, BMP4, and BMP6. In vitro treatment with BMP2 mirrored the effects of CA-MSCs on cancer stem cells while inhibiting BMP signaling, whereas, in vivo, BMP2 partially inhibited MSC-promoted tumor growth. These results imply that MSCs can promote tumor growth by increasing the CSC number through BMP expression [128].

\subsection{Promotion of Tumor Metastasis}

Along with the increasing number of cancer metastasis mechanisms being discovered, it has been reported that MSCs can induce metastasis in vitro and in vivo $[52,53,129,130]$. When breast cancer cells were co-incubated with human MSCs, the expression of oncogenes and proto-oncogenes was upregulated in breast cancer cells [116]. These molecular changes are accompanied by morphological alterations to a more metastatic phenotype. The breast cancer cells induce secretion of the CCL 5 which then induce tumor cell motility, invasiveness, and metastatic potentials [52]. CCL5/RANTES-mediated invasion is also closely related with increased activity of matrix metalloproteinase 9 (MMP-9) [38]. However, this enhanced metastatic ability is reversed when MSCs are injected into separate sites, even if those sites are in close proximity [52]. Other mechanisms such as induction of EMT, regulation of CSCs, and shifting of mesenchymal niches are also involved in tumor metastasis [131].

\subsection{Inhibition of Apoptosis in Tumor Cells}

MSCs can secrete cell regenerative factors continuously, but also secrete factors in response to other various stimuli [132]. Tumor progression is accompanied by hypoxia, starvation, and inflammation. In particular, it was shown that in vitro culture of MSCs under hypoxic conditions augmented cellular proliferation. Additionally, the expression of Rex-1 and Oct- 4 was increased, leading to the conclusion that MSC stemness was increased during hypoxia [133]. Moreover, under hypoxic and starved conditions, MSCs can survive via autophagy and release many anti-apoptotic or pro-survival factors, such as VEGF, FGF-2, PDGF, HGF, brain-derived neurotropic factor (BDNF), SDF-1 $\alpha$, IGF-1 and IGF-2, transforming growth factor- $\beta$ (TGF- $\beta$ ), and IGF binding protein-2 (IGFBP-2) $[28,134-138]$. These factors inhibit tumor cell apoptosis and promote tumor proliferation, while normal MSCs do not take on these properties. In addition to the mitogenic properties of growth factors secreted by MSCs, VEGF and FGF-2 can mediate the expression of Bcl-2, resulting in delaying apoptosis [139-141], while indirect 
angiogenic factors can induce the expression of VEGF and FGF-2 [142]. Moreover, SDF-1 $\alpha$ was reported to prevent drug-induced apoptosis of chronic lymphocytic leukemia (CLL) cells [143]. Furthermore, it has been reported that VEGF, FGF-2, HGF, and IGF-1 expressed by MSCs stimulate the angiogenic and anti-apoptotic effects after hypoxic conditioning [28,137]. Although little is known as to how MSCs under hypoxic conditions exert supportive effects on tumor cells directly, MSC-secreted growth factors stimulated by hypoxia can endow tumor supportive effects in the tumor microenvironment through angiogenic and anti-apoptotic effects.

\section{Suppression of Tumor Growth by MSCs}

Although many studies have shown that MSCs have tumor-promoting properties, many other studies have shown that MSCs have tumor-suppressive properties (Figure 1) (reviewed in [35]). In this regard, MSCs are thought to suppress tumor growth by increasing infiltration of inflammatory cells [144], inhibiting angiogenesis [47], suppressing the signaling of Wnt and AKT [40-42], and inducing cell cycle arrest and apoptosis [44-46,145]. Recently, Ryu et al. reported that when MSCs derived from adipose tissue was grown at high cell density, they synthesized IFN- $\beta$, which then suppressed the growth of MCF-7 cells [146]. Moreover, MSCs primed with IFN- $\gamma$ or cultured with tri-dimensional systems can express TRAIL, which induces tumor cell-specific apoptosis $[132,147]$.

\subsection{Induction of Apoptosis of Cancer Cells and Endothelial Cells}

Lu et al. demonstrated that MSCs had an inhibitory effect on mouse tumor cells and ascitogenic hepatoma cells in a cell-dependent manner through the caspase 3 pathway [145]. They also found that MSCs increased mRNA expression of p21, a negative regulator of cell cycle. Those data strongly implied that MSCs exerted tumor inhibitory effects in the absence of host immunosuppression, by inducing G0/G1 phase arrest and apoptosis of cancer cells [145]. In SCID mice xenografted with disseminated non-Hodgkin's lymphoma, MSCs displayed anti-cancer activity [148]. A single injection of MSC increased the survival of animals with aggressive lymphomas. It was also reported that a significant induction of endothelial cell apoptosis occurred in a direct co-culture of MSCs with endothelial cells, suggesting that MSCs exerted anti-angiogenic activity through endothelial cell apoptosis [148]. These findings were consistent with the results from studies that demonstrated that MSCs exhibited a potent anti-angiogenic activity in Kaposi sarcomas with high vascularity and in in vitro endothelial cell cultures $[40,47]$. Moreover, Dasari et al. reported that downregulation of the anti-apoptotic inhibitor, X-linked inhibitor of apoptosis protein (XIAP), by human umbilical cord blood-derived mesenchymal stem cell (hUCBSC) treatment induced apoptosis of glioma cells and xenograft cells through the activation of caspase-3 and caspase-9 [45,46]. Recently, MSCs cultured at a high density expressed type I IFN, leading to the cell death of breast cancer cells, MCF-7, and MDR-MB-231 cells [146]. Moreover, MSCs primed with IFN- $\gamma$ or cultured with tri-dimensional systems can express TRAIL, which induces tumor cell-specific apoptosis [132,147].

\subsection{Regulation of Cell Cycle}

MSCs secrete a variety of cytokines that induce cell cycle arrest of tumor cells, albeit transiently, at the G1 phase through expression of CyclinA, CyclinE, CyclinD2, and p27KIP1 [44,145,149-153]. Human stromal cells that were differentiated from adipose tissue (ADSC) and ADSC-conditioned cell culture medium suppressed tumors [145]. Furthermore, the ADSC-conditioned cell culture medium stimulated necrosis of cancer cells after G1-phase arrest in the absence of apoptosis. Finally, when ADSC was introduced into pancreatic adenocarcinoma, the tumor did not grow [145]. Similarly, tumor cells that were cultivated with MSCs in vitro also were arrested at the G1 phase [153]. However, when non-obese diabetic-severe combined immunodeficient mice were injected with MSCs and tumor cells, their growth was more augmented compared to tumor cell injection alone. Although it has been reported that MSCs can induce cell cycle arrest of tumor cells in vitro, little is known about the exact mechanisms. In our experiment, cell cycle retardation or arrest can be induced in certain tumor cell 
types and under certain co-culture conditions (type of media, cell concentration or co-culture time). While we cannot explain the exact mechanism(s), a number of studies by different groups, including ours, have shown that tumor cell cycle arrest does occur.

\subsection{Regulation of Cellular Signaling}

The phosphoinositide 3-kinase (PI3K)/AKT and WNT/ $\beta$-catenin signaling pathway controls cell survival, proliferation, growth, migration, and metabolism [154-159]. In tumor biology, numerous studies describe the requirement of AKT signaling for the migration, invasion, and survival of tumor cells. The WNT signaling pathway has also been associated with the development of carcinomas of the breast, liver, colon, skin, stomach, and ovary [160-171]. In a Kaposi's sarcoma model, intravenously injected MSCs migrated to tumors and effectively inhibited tumor proliferation through inhibition of AKT [40]. Moreover, in glioma cells, PTEN was upregulated by hUCBSCs, resulting in AKT downregulation [45]. In addition to inhibition of the PI3K/AKT signaling pathway, MSCs can also suppress the WNT/ $\beta$-catenin pathway through induced expression of DKK-1 [41-43]. These findings showed that $\beta$-catenin was downregulated in human carcinoma cell lines (hepatocellular, H7402 and HepG2; breast, MCF-7; hematopoietic, K562 and HL60) by DKK-1 secreted from MSCs. When DKK-1 activity was inhibited by either using neutralizing anti-DKK-1 antibodies or RNAi, an attenuation of the inhibitory effects of MSCs on tumor cell proliferation was observed [41-43].

\subsection{Induction of Inflammatory Infiltrates}

Although MSCs can suppress immune responses, Ohlsson et al. reported that co-administration of tumor cells and MSCs caused increased infiltration of granulocytes and monocytes than did separate treatments with tumor cells or MSCs alone in vivo [144]. They used a preformed gelatin matrix incorporating rat colon cancer cells and/or MSCs, which were then surgically transplanted subcutaneously into rats to monitor tumor outgrowth and the ensuing inflammatory response. MSCs inhibited rat colon carcinoma [144]. The increased infiltrations of both granulocytes and macrophages were noted to be much higher in rats co-injected with tumors and MSCs than in rats injected with tumors without MSCs. These data suggested that MSCs had pro-inflammatory effects in this model, although expression of MHC-class I was low and MHC-class II was absent in MSCs. In fact, the researchers observed that an increased degree of infiltration of granulocytes and macrophages was also seen, but to a lesser extent, when only MSCs were added to the gelatin [144].

\section{MSCs as Delivery Vehicles for Pro-Apoptotic Agents}

Regardless of delivery routes such as intravenous [40,50,172-175], intraperitoneal [176], or intracerebral [173], MSCs have the ability to migrate and infiltrate into the tumor microenvironment [177-181]. However, it is known that systemic administration of MSCs into the vascular system result in accumulation of MSCs in the lung in large numbers [182,183]. Moreover, in the case of MSC therapy for liver failure, depending on the route of injection and the status of the liver, MSCs can differentiate into myofibroblasts $[184,185]$. Thus, the route of injection and the optimal therapeutic timing according to disease status, including tumor status, must be considered to reduce the side effects of MSCs. Janowski et al. reported that cell number and infusion velocity are critical factors in developing safe protocols for stem cell transplantation [186]. Furthermore, Schrepfer et al. demonstrated that pretreatment with intravenous sodium nitroprusside can decrease cell trapping in the lungs [187].

Based on this capability of homing to the tumor, MSCs can be utilized to deliver pro-apoptotic agents straight into the tumor microenvironment. Numerous studies have used MSCs engineered to express and deliver a variety of anti-cancer drugs, such as type I interferon (IFN- $\alpha$ and IFN- $\beta$ ), IL-12, IL-2, CXCL1, oncolytic virus, cytokine deaminase, nanoparticles, and TRAIL [50,172,173,176,188-202]. IL-2 over-expressing MSCs improve immune surveillance against glioma [192] and melanoma [203] and reduce metastasis from a subcutaneous model [193]. CXCL1 and IL-12 expressed by MSCs 
activate both T cells and NK cells, and result in a substantial decrease in lung and breast tumors and melanoma $[175,191,193,195,204]$. Because the local concentrations of IFN- $\alpha$, IFN- $\beta$, and TRAIL can be increased by genetically engineered MSCs, the activities of IFN- $\alpha$, IFN- $\beta$, and TRAIL on suppression of tumor mass and animal survival are potentiated more effectively than are the activities of IFN- $\alpha$, IFN- $\beta$ and TRAIL used in a systematical treatment [50,173,188-190]. MSCs have also been engineered to deliver conditional replicative oncolytic viruses, which selectively target and inhibit tumor cells without affecting normal cells, to diminish tumor growth and metastasis [176,196,197,205]. Furthermore, MSCs can be used to increase targeting efficiency of nanoparticulate drug delivery system-based cancer therapies [200], and to enhance the cytotoxicity of pro-drugs by having a converting enzyme expressed in MSCs at the site of a tumor [198,199,206-209].

\section{Conclusions}

Although MSC therapy in regenerative medicine is considered feasible and safe in patients [210], the ability of MSCs to promote tumorigenesis of pre-existing tumors must be scrutinized. This review highlights the mechanisms of MSC-mediated effects of tumor support or suppression and then discusses the possible modulation of MSCs for tumor therapy. MSCs demonstrate a tropism for tumors and then infiltrate the tumor stroma [50,51]. These cells interact with each other and with cancer cells, resulting in promotion of tumor growth. MSCs contribute to tumor growth promotion in several mechanisms, including (1) by transition to tumor associated fibroblasts; (2) by suppression of the immune response; (3) by promotion of angiogenesis; (4) by stimulation of the epithelial-mesenchymal transition (EMT); (5) through contribution to the tumor microenvironment; (6) by inhibition of tumor cell apoptosis; and (7) via promotion of tumor metastasis. In contrast to the tumor-augmenting characteristics, many studies have reported that MSCs can prevent growth of tumors [35]. MSCs inhibit tumor growth by increasing inflammatory infiltration [144], inhibiting angiogenesis [47], suppressing the signaling of Wnt [41,42] and AKT [40], and inducing cell cycle arrest and apoptosis [44-46,145]. In spite of these tumor-suppressive mechanisms, not much is understood regarding the molecular mechanisms by which MSCs inhibit tumor cells because it has not yet been shown which ligand induces the suppression of tumor growth. MSCs and tumor cells interact in a myriad of ways and thus the MSCs can either support or suppress tumor growth depending on multiple factors. Myriad cell types can influence tumor progression. Moreover, the timing of MSC introduction into the tumor microenvironment may be critical to elucidate the dual role of MSCs in tumor support or suppression. In several studies, tumor growth inhibition was observed when MSCs were introduced into established tumors and when direct contact of MSCs and tumor was suppressed by gelatin matrix or intravenous delivery of MSCs during tumor initiation [40,144]. By contrast, many studies have demonstrated that the tumor was promoted when MSCs and tumor cells were injected simultaneously [52-56]. Based on a marked tropism of MSCs for tumors, MSCs can be applied to deliver pro-apoptotic agents directly into the tumor microenvironment for tumor therapy. More robust studies characterizing the mechanisms of tumor support or suppression by MSCs may increase the utilization of MSCs in regenerative medicine without risk of promoting pre-existing tumor cell growth and advance the possibility of developing therapeutic strategies using MSCs with minimal side effects.

Acknowledgments: This research was supported by the Basic Science Research Program through the National Research Foundation of Korea (NRF), funded by the Ministry of Education (NRF-2012R1A1A2004981).

Author Contributions: Young Woo Eom conceived the idea and wrote the manuscript; Ki-Jong Rhee and Jong In Lee were involved in discussion, contributed to manuscript preparation, and critically reviewed the manuscript. Ki-Jong Rhee and Jong In Lee contributed equally to this work. All authors approved the final manuscript.

Conflicts of Interest: The authors declare no conflict of interest. 


\section{References}

1. Dominici, M.; le Blanc, K.; Mueller, I.; Slaper-Cortenbach, I.; Marini, F.; Krause, D.; Deans, R.; Keating, A.; Prockop, D.; Horwitz, E. Minimal criteria for defining multipotent mesenchymal stromal cells. The International Society for Cellular Therapy position statement. Cytotherapy 2006, 8, 315-317. [CrossRef] [PubMed]

2. Campagnoli, C.; Roberts, I.A.; Kumar, S.; Bennett, P.R.; Bellantuono, I.; Fisk, N.M. Identification of mesenchymal stem/progenitor cells in human first-trimester fetal blood, liver, and bone marrow. Blood 2001, 98, 2396-2402. [CrossRef] [PubMed]

3. De Ugarte, D.A.; Morizono, K.; Elbarbary, A.; Alfonso, Z.; Zuk, P.A.; Zhu, M.; Dragoo, J.L.; Ashjian, P.; Thomas, B.; Benhaim, P.; et al. Comparison of multi-lineage cells from human adipose tissue and bone marrow. Cells Tissues Organs 2003, 174, 101-109. [CrossRef] [PubMed]

4. Erices, A.; Conget, P.; Minguell, J.J. Mesenchymal progenitor cells in human umbilical cord blood. Br. J. Haematol. 2000, 109, 235-242. [CrossRef] [PubMed]

5. Jiang, Y.; Vaessen, B.; Lenvik, T.; Blackstad, M.; Reyes, M.; Verfaillie, C.M. Multipotent progenitor cells can be isolated from postnatal murine bone marrow, muscle, and brain. Exp. Hematol. 2002, 30, 896-904. [CrossRef]

6. Young, H.E.; Steele, T.A.; Bray, R.A.; Hudson, J.; Floyd, J.A.; Hawkins, K.; Thomas, K.; Austin, T.; Edwards, C.; Cuzzourt, J.; et al. Human reserve pluripotent mesenchymal stem cells are present in the connective tissues of skeletal muscle and dermis derived from fetal, adult, and geriatric donors. Anat. Rec. 2001, 264, 51-62. [CrossRef] [PubMed]

7. Zvaifler, N.J.; Marinova-Mutafchieva, L.; Adams, G.; Edwards, C.J.; Moss, J.; Burger, J.A.; Maini, R.N. Mesenchymal precursor cells in the blood of normal individuals. Arthritis Res. 2000, 2, 477-488. [CrossRef] [PubMed]

8. Yoo, K.H.; Jang, I.K.; Lee, M.W.; Kim, H.E.; Yang, M.S.; Eom, Y.; Lee, J.E.; Kim, Y.J.; Yang, S.K.; Jung, H.L.; et al. Comparison of immunomodulatory properties of mesenchymal stem cells derived from adult human tissues. Cell. Immunol. 2009, 259, 150-156. [CrossRef] [PubMed]

9. Pendleton, C.; Li, Q.; Chesler, D.A.; Yuan, K.; Guerrero-Cazares, H.; Quinones-Hinojosa, A. Mesenchymal stem cells derived from adipose tissue $v$ s bone marrow: In vitro comparison of their tropism towards gliomas. PLoS ONE 2013, 8. [CrossRef] [PubMed]

10. Kidd, S.; Spaeth, E.; Watson, K.; Burks, J.; Lu, H.; Klopp, A.; Andreeff, M.; Marini, F.C. Origins of the tumor microenvironment: Quantitative assessment of adipose-derived and bone marrow-derived stroma. PLoS ONE 2012, 7. [CrossRef] [PubMed]

11. Jansen, B.J.; Gilissen, C.; Roelofs, H.; Schaap-Oziemlak, A.; Veltman, J.A.; Raymakers, R.A.; Jansen, J.H.; Kogler, G.; Figdor, C.G.; Torensma, R.; et al. Functional differences between mesenchymal stem cell populations are reflected by their transcriptome. Stem Cells Dev. 2010, 19, 481-490. [CrossRef] [PubMed]

12. Mosna, F.; Sensebe, L.; Krampera, M. Human bone marrow and adipose tissue mesenchymal stem cells: A user's guide. Stem Cells Dev. 2010, 19, 1449-1470. [CrossRef] [PubMed]

13. Uccelli, A.; Moretta, L.; Pistoia, V. Mesenchymal stem cells in health and disease. Nat. Rev. Immunol. 2008, 8, 726-736. [CrossRef] [PubMed]

14. Liu, Z.J.; Zhuge, Y.; Velazquez, O.C. Trafficking and differentiation of mesenchymal stem cells. J. Cell. Biochem. 2009, 106, 984-991. [CrossRef] [PubMed]

15. Haynesworth, S.E.; Goshima, J.; Goldberg, V.M.; Caplan, A.I. Characterization of cells with osteogenic potential from human marrow. Bone 1992, 13, 81-88. [CrossRef]

16. Pittenger, M.F.; Mackay, A.M.; Beck, S.C.; Jaiswal, R.K.; Douglas, R.; Mosca, J.D.; Moorman, M.A.; Simonetti, D.W.; Craig, S.; Marshak, D.R. Multilineage potential of adult human mesenchymal stem cells. Science 1999, 284, 143-147. [CrossRef] [PubMed]

17. Prockop, D.J. Marrow stromal cells as stem cells for nonhematopoietic tissues. Science 1997, 276, 71-74. [CrossRef] [PubMed]

18. Dai, L.J.; Li, H.Y.; Guan, L.X.; Ritchie, G.; Zhou, J.X. The therapeutic potential of bone marrow-derived mesenchymal stem cells on hepatic cirrhosis. Stem Cell Res. 2009, 2, 16-25. [CrossRef] [PubMed]

19. Sharma, R.R.; Pollock, K.; Hubel, A.; McKenna, D. Mesenchymal stem or stromal cells: A review of clinical applications and manufacturing practices. Transfusion 2014, 54, 1418-1437. [CrossRef] [PubMed] 
20. Augello, A.; Tasso, R.; Negrini, S.M.; Amateis, A.; Indiveri, F.; Cancedda, R.; Pennesi, G. Bone marrow mesenchymal progenitor cells inhibit lymphocyte proliferation by activation of the programmed death 1 pathway. Eur. J. Immunol. 2005, 35, 1482-1490. [CrossRef] [PubMed]

21. Haddad, R.; Saldanha-Araujo, F. Mechanisms of T-cell immunosuppression by mesenchymal stromal cells: What do we know so far? Biomed. Res. Int. 2014, 2014. [CrossRef] [PubMed]

22. Najar, M.; Raicevic, G.; Fayyad-Kazan, H.; de Bruyn, C.; Bron, D.; Toungouz, M.; Lagneaux, L. Immune-related antigens, surface molecules and regulatory factors in human-derived mesenchymal stromal cells: The expression and impact of inflammatory priming. Stem Cell Rev. 2012, 8, 1188-1198. [CrossRef] [PubMed]

23. Kupcova-Skalnikova, H. Proteomic techniques for characterisation of mesenchymal stem cell secretome. Biochimie 2013, 95, 2196-2211. [CrossRef] [PubMed]

24. Sakaida, I.; Terai, S.; Yamamoto, N.; Aoyama, K.; Ishikawa, T.; Nishina, H.; Okita, K. Transplantation of bone marrow cells reduces $\mathrm{CCl}_{4}$-induced liver fibrosis in mice. Hepatology 2004, 40, 1304-1311. [CrossRef] [PubMed]

25. Wang, L.; Wang, X.; Wang, L.; Chiu, J.D.; van de Ven, G.; Gaarde, W.A.; Deleve, L.D. Hepatic vascular endothelial growth factor regulates recruitment of rat liver sinusoidal endothelial cell progenitor cells. Gastroenterology 2012, 143, 1555-1563. [CrossRef] [PubMed]

26. Kim, S.U.; Oh, H.J.; Wanless, I.R.; Lee, S.; Han, K.H.; Park, Y.N. The Laennec staging system for histological sub-classification of cirrhosis is useful for stratification of prognosis in patients with liver cirrhosis. J. Hepatol. 2012, 57, 556-563. [CrossRef] [PubMed]

27. Wu, Y.; Zhao, R.C.; Tredget, E.E. Concise review: Bone marrow-derived stem/progenitor cells in cutaneous repair and regeneration. Stem Cells 2010, 28, 905-915. [PubMed]

28. Crisostomo, P.R.; Wang, Y.; Markel, T.A.; Wang, M.; Lahm, T.; Meldrum, D.R. Human mesenchymal stem cells stimulated by TNF- $\alpha$, LPS, or hypoxia produce growth factors by an NFKB- but not JNK-dependent mechanism. Am. J. Physiol. Cell Physiol. 2008, 294, C675-C682. [CrossRef] [PubMed]

29. Caplan, A.I.; Dennis, J.E. Mesenchymal stem cells as trophic mediators. J. Cell. Biochem. 2006, 98, 1076-1084. [CrossRef] [PubMed]

30. Beckermann, B.M.; Kallifatidis, G.; Groth, A.; Frommhold, D.; Apel, A.; Mattern, J.; Salnikov, A.V.; Moldenhauer, G.; Wagner, W.; Diehlmann, A.; et al. VEGF expression by mesenchymal stem cells contributes to angiogenesis in pancreatic carcinoma. Br. J. Cancer 2008, 99, 622-631. [CrossRef] [PubMed]

31. Block, G.J.; Ohkouchi, S.; Fung, F.; Frenkel, J.; Gregory, C.; Pochampally, R.; DiMattia, G.; Sullivan, D.E.; Prockop, D.J. Multipotent stromal cells are activated to reduce apoptosis in part by upregulation and secretion of stanniocalcin-1. Stem Cells 2009, 27, 670-681. [CrossRef] [PubMed]

32. Dvorak, H.F. Tumors: Wounds that do not heal. Similarities between tumor stroma generation and wound healing. N. Engl. J. Med. 1986, 315, 1650-1659. [PubMed]

33. Kaneko, Y.; Tajiri, N.; Staples, M.; Reyes, S.; Lozano, D.; Sanberg, P.R.; Freeman, T.B.; van Loveren, H.; Kim, S.U.; Borlongan, C.V. Bone marrow-derived stem cell therapy for metastatic brain cancers. Cell Transplant. 2015, 24, 625-630. [CrossRef] [PubMed]

34. Hanahan, D.; Weinberg, R.A. Hallmarks of cancer: The next generation. Cell 2011, 144, 646-674. [CrossRef] [PubMed]

35. Klopp, A.H.; Gupta, A.; Spaeth, E.; Andreeff, M.; Marini, F., 3rd. Concise review: Dissecting a discrepancy in the literature: Do mesenchymal stem cells support or suppress tumor growth? Stem Cells 2011, 29, 11-19. [CrossRef] [PubMed]

36. Zhang, Y.; Daquinag, A.; Traktuev, D.O.; Amaya-Manzanares, F.; Simmons, P.J.; March, K.L.; Pasqualini, R.; Arap, W.; Kolonin, M.G. White adipose tissue cells are recruited by experimental tumors and promote cancer progression in mouse models. Cancer Res. 2009, 69, 5259-5266. [CrossRef] [PubMed]

37. Jotzu, C.; Alt, E.; Welte, G.; Li, J.; Hennessy, B.T.; Devarajan, E.; Krishnappa, S.; Pinilla, S.; Droll, L.; Song, Y.H. Adipose tissue derived stem cells differentiate into carcinoma-associated fibroblast-like cells under the influence of tumor derived factors. Cell. Oncol. 2011, 34, 55-67. [CrossRef] [PubMed]

38. Pinilla, S.; Alt, E.; Abdul Khalek, F.J.; Jotzu, C.; Muehlberg, F.; Beckmann, C.; Song, Y.H. Tissue resident stem cells produce CCL5 under the influence of cancer cells and thereby promote breast cancer cell invasion. Cancer Lett. 2009, 284, 80-85. [CrossRef] [PubMed] 
39. Krohn, A.; Song, Y.H.; Muehlberg, F.; Droll, L.; Beckmann, C.; Alt, E. CXCR4 receptor positive spheroid forming cells are responsible for tumor invasion in vitro. Cancer Lett. 2009, 280, 65-71. [CrossRef] [PubMed]

40. Khakoo, A.Y.; Pati, S.; Anderson, S.A.; Reid, W.; Elshal, M.F.; Rovira, I.I.; Nguyen, A.T.; Malide, D.; Combs, C.A.; Hall, G.; et al. Human mesenchymal stem cells exert potent antitumorigenic effects in a model of Kaposi's sarcoma. J. Exp. Med. 2006, 203, 1235-1247. [CrossRef] [PubMed]

41. Qiao, L.; Xu, Z.; Zhao, T.; Zhao, Z.; Shi, M.; Zhao, R.C.; Ye, L.; Zhang, X. Suppression of tumorigenesis by human mesenchymal stem cells in a hepatoma model. Cell Res. 2008, 18, 500-507. [CrossRef] [PubMed]

42. Qiao, L.; Xu, Z.L.; Zhao, T.J.; Ye, L.H.; Zhang, X.D. Dkk-1 secreted by mesenchymal stem cells inhibits growth of breast cancer cells via depression of Wnt signalling. Cancer Lett. 2008, 269, 67-77. [CrossRef] [PubMed]

43. Zhu, Y.; Sun, Z.; Han, Q.; Liao, L.; Wang, J.; Bian, C.; Li, J.; Yan, X.; Liu, Y.; Shao, C.; et al. Human mesenchymal stem cells inhibit cancer cell proliferation by secreting DKK-1. Leukemia 2009, 23, 925-933. [CrossRef] [PubMed]

44. Cousin, B.; Ravet, E.; Poglio, S.; de Toni, F.; Bertuzzi, M.; Lulka, H.; Touil, I.; Andre, M.; Grolleau, J.L.; Peron, J.M.; et al. Adult stromal cells derived from human adipose tissue provoke pancreatic cancer cell death both in vitro and in vivo. PLoS ONE 2009, 4. [CrossRef] [PubMed]

45. Dasari, V.R.; Kaur, K.; Velpula, K.K.; Gujrati, M.; Fassett, D.; Klopfenstein, J.D.; Dinh, D.H.; Rao, J.S. Upregulation of PTEN in glioma cells by cord blood mesenchymal stem cells inhibits migration via downregulation of the PI3K/Akt pathway. PLoS ONE 2010, 5. [CrossRef] [PubMed]

46. Dasari, V.R.; Velpula, K.K.; Kaur, K.; Fassett, D.; Klopfenstein, J.D.; Dinh, D.H.; Gujrati, M.; Rao, J.S. Cord blood stem cell-mediated induction of apoptosis in glioma downregulates X-linked inhibitor of apoptosis protein (XIAP). PLoS ONE 2010, 5. [CrossRef] [PubMed]

47. Otsu, K.; Das, S.; Houser, S.D.; Quadri, S.K.; Bhattacharya, S.; Bhattacharya, J. Concentration-dependent inhibition of angiogenesis by mesenchymal stem cells. Blood 2009, 113, 4197-4205. [CrossRef] [PubMed]

48. Li, H.; Fan, X.; Houghton, J. Tumor microenvironment: The role of the tumor stroma in cancer. J. Cell. Biochem. 2007, 101, 805-815. [CrossRef] [PubMed]

49. Bissell, M.J.; Radisky, D. Putting tumours in context. Nat. Rev. Cancer 2001, 1, 46-54. [CrossRef] [PubMed]

50. Studeny, M.; Marini, F.C.; Dembinski, J.L.; Zompetta, C.; Cabreira-Hansen, M.; Bekele, B.N.; Champlin, R.E.; Andreeff, M. Mesenchymal stem cells: Potential precursors for tumor stroma and targeted-delivery vehicles for anticancer agents. J. Natl. Cancer Inst. 2004, 96, 1593-1603. [CrossRef] [PubMed]

51. Kidd, S.; Spaeth, E.; Dembinski, J.L.; Dietrich, M.; Watson, K.; Klopp, A.; Battula, V.L.; Weil, M.; Andreeff, M.; Marini, F.C. Direct evidence of mesenchymal stem cell tropism for tumor and wounding microenvironments using in vivo bioluminescent imaging. Stem Cells 2009, 27, 2614-2623. [CrossRef] [PubMed]

52. Karnoub, A.E.; Dash, A.B.; Vo, A.P.; Sullivan, A.; Brooks, M.W.; Bell, G.W.; Richardson, A.L.; Polyak, K.; Tubo, R.; Weinberg, R.A. Mesenchymal stem cells within tumour stroma promote breast cancer metastasis. Nature 2007, 449, 557-563. [CrossRef] [PubMed]

53. Xu, W.T.; Bian, Z.Y.; Fan, Q.M.; Li, G.; Tang, T.T. Human mesenchymal stem cells (HMSCs) target osteosarcoma and promote its growth and pulmonary metastasis. Cancer Lett. 2009, 281, 32-41. [CrossRef] [PubMed]

54. Zhu, W.; Xu, W.; Jiang, R.; Qian, H.; Chen, M.; Hu, J.; Cao, W.; Han, C.; Chen, Y. Mesenchymal stem cells derived from bone marrow favor tumor cell growth in vivo. Exp. Mol. Pathol. 2006, 80, 267-274. [CrossRef] [PubMed]

55. Spaeth, E.L.; Dembinski, J.L.; Sasser, A.K.; Watson, K.; Klopp, A.; Hall, B.; Andreeff, M.; Marini, F. Mesenchymal stem cell transition to tumor-associated fibroblasts contributes to fibrovascular network expansion and tumor progression. PLoS ONE 2009, 4. [CrossRef] [PubMed]

56. Djouad, F.; Plence, P.; Bony, C.; Tropel, P.; Apparailly, F.; Sany, J.; Noel, D.; Jorgensen, C. Immunosuppressive effect of mesenchymal stem cells favors tumor growth in allogeneic animals. Blood 2003, 102, 3837-3844. [CrossRef] [PubMed]

57. Mueller, M.M.; Fusenig, N.E. Friends or foes-Bipolar effects of the tumour stroma in cancer. Nat. Rev. Cancer 2004, 4, 839-849. [CrossRef] [PubMed]

58. Sappino, A.P.; Skalli, O.; Jackson, B.; Schurch, W.; Gabbiani, G. Smooth-muscle differentiation in stromal cells of malignant and non-malignant breast tissues. Int. J. Cancer 1988, 41, 707-712. [CrossRef] [PubMed] 
59. Orimo, A.; Gupta, P.B.; Sgroi, D.C.; Arenzana-Seisdedos, F.; Delaunay, T.; Naeem, R.; Carey, V.J.; Richardson, A.L.; Weinberg, R.A. Stromal fibroblasts present in invasive human breast carcinomas promote tumor growth and angiogenesis through elevated SDF-1/CXCL12 secretion. Cell 2005, 121, 335-348. [CrossRef] [PubMed]

60. Muller, A.; Homey, B.; Soto, H.; Ge, N.; Catron, D.; Buchanan, M.E.; McClanahan, T.; Murphy, E.; Yuan, W.; Wagner, S.N.; et al. Involvement of chemokine receptors in breast cancer metastasis. Nature 2001, 410, 50-56. [CrossRef] [PubMed]

61. Mishra, P.J.; Mishra, P.J.; Humeniuk, R.; Medina, D.J.; Alexe, G.; Mesirov, J.P.; Ganesan, S.; Glod, J.W.; Banerjee, D. Carcinoma-associated fibroblast-like differentiation of human mesenchymal stem cells. Cancer Res. 2008, 68, 4331-4339. [CrossRef] [PubMed]

62. Quante, M.; Tu, S.P.; Tomita, H.; Gonda, T.; Wang, S.S.; Takashi, S.; Baik, G.H.; Shibata, W.; Diprete, B.; Betz, K.S.; et al. Bone marrow-derived myofibroblasts contribute to the mesenchymal stem cell niche and promote tumor growth. Cancer Cell 2011, 19, 257-272. [CrossRef] [PubMed]

63. Wang, D.; Park, J.S.; Chu, J.S.; Krakowski, A.; Luo, K.; Chen, D.J.; Li, S. Proteomic profiling of bone marrow mesenchymal stem cells upon transforming growth factor $\beta 1$ stimulation. J. Biol. Chem. 2004, 279, 43725-43734. [CrossRef] [PubMed]

64. Robbins, P.F.; Lu, Y.C.; El-Gamil, M.; Li, Y.F.; Gross, C.; Gartner, J.; Lin, J.C.; Teer, J.K.; Cliften, P.; Tycksen, E.; et al. Mining exomic sequencing data to identify mutated antigens recognized by adoptively transferred tumor-reactive T cells. Nat. Med. 2013, 19, 747-752. [CrossRef] [PubMed]

65. Matsushita, H.; Vesely, M.D.; Koboldt, D.C.; Rickert, C.G.; Uppaluri, R.; Magrini, V.J.; Arthur, C.D.; White, J.M.; Chen, Y.S.; Shea, L.K.; et al. Cancer exome analysis reveals a T-cell-dependent mechanism of cancer immunoediting. Nature 2012, 482, 400-404. [CrossRef] [PubMed]

66. Mantovani, A.; Schioppa, T.; Porta, C.; Allavena, P.; Sica, A. Role of tumor-associated macrophages in tumor progression and invasion. Cancer Metastasis Rev. 2006, 25, 315-322. [CrossRef] [PubMed]

67. Sica, A.; Schioppa, T.; Mantovani, A.; Allavena, P. Tumour-associated macrophages are a distinct M2 polarised population promoting tumour progression: Potential targets of anti-cancer therapy. Eur. J. Cancer 2006, 42, 717-727. [CrossRef] [PubMed]

68. Condeelis, J.; Pollard, J.W. Macrophages: Obligate partners for tumor cell migration, invasion, and metastasis. Cell 2006, 124, 263-266. [CrossRef] [PubMed]

69. Lamagna, C.; Aurrand-Lions, M.; Imhof, B.A. Dual role of macrophages in tumor growth and angiogenesis. J. Leukoc. Biol. 2006, 80, 705-713. [CrossRef] [PubMed]

70. Coffelt, S.B.; Hughes, R.; Lewis, C.E. Tumor-associated macrophages: Effectors of angiogenesis and tumor progression. Biochim. Biophys. Acta 2009, 1796, 11-18. [CrossRef] [PubMed]

71. Siveen, K.S.; Kuttan, G. Role of macrophages in tumour progression. Immunol. Lett. 2009, 123, 97-102. [CrossRef] [PubMed]

72. Lewis, C.E.; Pollard, J.W. Distinct role of macrophages in different tumor microenvironments. Cancer Res. 2006, 66, 605-612. [CrossRef] [PubMed]

73. Mantovani, A.; Sica, A.; Allavena, P.; Garlanda, C.; Locati, M. Tumor-associated macrophages and the related myeloid-derived suppressor cells as a paradigm of the diversity of macrophage activation. Hum. Immunol. 2009, 70, 325-330. [CrossRef] [PubMed]

74. Mills, C.D.; Kincaid, K.; Alt, J.M.; Heilman, M.J.; Hill, A.M. M-1/M-2 macrophages and the Th1/Th2 paradigm. J. Immunol. 2000, 164, 6166-6173. [CrossRef] [PubMed]

75. Leek, R.D.; Hunt, N.C.; Landers, R.J.; Lewis, C.E.; Royds, J.A.; Harris, A.L. Macrophage infiltration is associated with VEGF and EGFR expression in breast cancer. J. Pathol. 2000, 190, 430-436. [CrossRef]

76. Zhang, J.; Lu, Y.; Pienta, K.J. Multiple roles of chemokine (C-C motif) ligand 2 in promoting prostate cancer growth. J. Natl. Cancer Inst. 2010, 102, 522-528. [CrossRef] [PubMed]

77. Kosaka, T.; Kuwabara, M.; Endo, A.; Tamaguchi, H.; Koide, F. Expression of arginase by mouse myeloid leukemic cell differentiation in vitro induced with tumor necrosis factor. J. Vet. Med. Sci. 1991, 53, 53-57. [CrossRef] [PubMed]

78. Tsung, K.; Dolan, J.P.; Tsung, Y.L.; Norton, J.A. Macrophages as effector cells in interleukin 12-induced T cell-dependent tumor rejection. Cancer Res. 2002, 62, 5069-5075. [PubMed]

79. Brigati, C.; Noonan, D.M.; Albini, A.; Benelli, R. Tumors and inflammatory infiltrates: Friends or foes? Clin. Exp. Metastasis 2002, 19, 247-258. [CrossRef] [PubMed] 
80. Bingle, L.; Brown, N.J.; Lewis, C.E. The role of tumour-associated macrophages in tumour progression: Implications for new anticancer therapies. J. Pathol. 2002, 196, 254-265. [CrossRef] [PubMed]

81. Leek, R.D.; Harris, A.L. Tumor-associated macrophages in breast cancer. J. Mammary Gland Biol. Neoplasia 2002, 7, 177-189. [CrossRef] [PubMed]

82. Van der Bij, G.J.; Oosterling, S.J.; Meijer, S.; Beelen, R.H.; van Egmond, M. The role of macrophages in tumor development. Cell. Oncol. 2005, 27, 203-213. [PubMed]

83. Li, H.J.; Reinhardt, F.; Herschman, H.R.; Weinberg, R.A. Cancer-stimulated mesenchymal stem cells create a carcinoma stem cell niche via prostaglandin $\mathrm{E}_{2}$ signaling. Cancer Discov. 2012, 2, 840-855. [CrossRef] [PubMed]

84. Nakao, S.; Kuwano, T.; Tsutsumi-Miyahara, C.; Ueda, S.; Kimura, Y.N.; Hamano, S.; Sonoda, K.H.; Saijo, Y.; Nukiwa, T.; Strieter, R.M.; et al. Infiltration of COX-2-expressing macrophages is a prerequisite for IL-1 $\beta$-induced neovascularization and tumor growth. J. Clin. Investig. 2005, 115, 2979-2991. [CrossRef] [PubMed]

85. Torisu, H.; Ono, M.; Kiryu, H.; Furue, M.; Ohmoto, Y.; Nakayama, J.; Nishioka, Y.; Sone, S.; Kuwano, M. Macrophage infiltration correlates with tumor stage and angiogenesis in human malignant melanoma: Possible involvement of TNF $\alpha$ and IL-1 $\alpha$. Int. J. Cancer 2000, 85, 182-188. [CrossRef]

86. Voswinkel, J.; Francois, S.; Simon, J.M.; Benderitter, M.; Gorin, N.C.; Mohty, M.; Fouillard, L.; Chapel, A. Use of mesenchymal stem cells (MSC) in chronic inflammatory fistulizing and fibrotic diseases: A comprehensive review. Clin. Rev. Allergy Immunol. 2013, 45, 180-192. [CrossRef] [PubMed]

87. Volarevic, V.; al-Qahtani, A.; Arsenijevic, N.; Pajovic, S.; Lukic, M.L. Interleukin-1 receptor antagonist (IL-1Ra) and IL-1Ra producing mesenchymal stem cells as modulators of diabetogenesis. Autoimmunity 2010, 43, 255-263. [CrossRef] [PubMed]

88. Parekkadan, B.; van Poll, D.; Suganuma, K.; Carter, E.A.; Berthiaume, F.; Tilles, A.W.; Yarmush, M.L. Mesenchymal stem cell-derived molecules reverse fulminant hepatic failure. PLoS ONE 2007, 2. [CrossRef] [PubMed]

89. Nemeth, K.; Leelahavanichkul, A.; Yuen, P.S.; Mayer, B.; Parmelee, A.; Doi, K.; Robey, P.G.; Leelahavanichkul, K.; Koller, B.H.; Brown, J.M.; et al. Bone marrow stromal cells attenuate sepsis via prostaglandin $\mathrm{E}_{2}$-dependent reprogramming of host macrophages to increase their interleukin-10 production. Nat. Med. 2009, 15, 42-49. [CrossRef] [PubMed]

90. Spaggiari, G.M.; Abdelrazik, H.; Becchetti, F.; Moretta, L. MSCs inhibit monocyte-derived DC maturation and function by selectively interfering with the generation of immature DCs: Central role of MSC-derived prostaglandin $\mathrm{E}_{2}$. Blood 2009, 113, 6576-6583. [CrossRef] [PubMed]

91. Djouad, F.; Charbonnier, L.M.; Bouffi, C.; Louis-Plence, P.; Bony, C.; Apparailly, F.; Cantos, C.; Jorgensen, C.; Noel, D. Mesenchymal stem cells inhibit the differentiation of dendritic cells through an interleukin-6-dependent mechanism. Stem Cells 2007, 25, 2025-2032. [CrossRef] [PubMed]

92. Jiang, X.X.; Zhang, Y.; Liu, B.; Zhang, S.X.; Wu, Y.; Yu, X.D.; Mao, N. Human mesenchymal stem cells inhibit differentiation and function of monocyte-derived dendritic cells. Blood 2005, 105, 4120-4126. [CrossRef] [PubMed]

93. Ren, G.; Su, J.; Zhang, L.; Zhao, X.; Ling, W.; L'Huillie, A.; Zhang, J.; Lu, Y.; Roberts, A.I.; Ji, W.; et al. Species variation in the mechanisms of mesenchymal stem cell-mediated immunosuppression. Stem Cells 2009, 27, 1954-1962. [CrossRef] [PubMed]

94. Sato, K.; Ozaki, K.; Oh, I.; Meguro, A.; Hatanaka, K.; Nagai, T.; Muroi, K.; Ozawa, K. Nitric oxide plays a critical role in suppression of T-cell proliferation by mesenchymal stem cells. Blood 2007, 109, 228-234. [CrossRef] [PubMed]

95. Green, S.J.; Scheller, L.F.; Marletta, M.A.; Seguin, M.C.; Klotz, F.W.; Slayter, M.; Nelson, B.J.; Nacy, C.A. Nitric oxide: Cytokine-regulation of nitric oxide in host resistance to intracellular pathogens. Immunol. Lett. 1994, 43, 87-94. [CrossRef]

96. Ren, G.; Zhang, L.; Zhao, X.; Xu, G.; Zhang, Y.; Roberts, A.I.; Zhao, R.C.; Shi, Y. Mesenchymal stem cell-mediated immunosuppression occurs via concerted action of chemokines and nitric oxide. Cell Stem Cell 2008, 2, 141-150. [CrossRef] [PubMed]

97. Mazzoni, A.; Bronte, V.; Visintin, A.; Spitzer, J.H.; Apolloni, E.; Serafini, P.; Zanovello, P.; Segal, D.M. Myeloid suppressor lines inhibit $\mathrm{T}$ cell responses by an no-dependent mechanism. J. Immunol. 2002, 168, 689-695. [CrossRef] [PubMed] 
98. Rajantie, I.; Ilmonen, M.; Alminaite, A.; Ozerdem, U.; Alitalo, K.; Salven, P. Adult bone marrow-derived cells recruited during angiogenesis comprise precursors for periendothelial vascular mural cells. Blood 2004, 104, 2084-2086. [CrossRef] [PubMed]

99. Bexell, D.; Gunnarsson, S.; Tormin, A.; Darabi, A.; Gisselsson, D.; Roybon, L.; Scheding, S.; Bengzon, J. Bone marrow multipotent mesenchymal stroma cells act as pericyte-like migratory vehicles in experimental gliomas. Mol. Ther. 2009, 17, 183-190. [CrossRef] [PubMed]

100. Kinnaird, T.; Stabile, E.; Burnett, M.S.; Lee, C.W.; Barr, S.; Fuchs, S.; Epstein, S.E. Marrow-derived stromal cells express genes encoding a broad spectrum of arteriogenic cytokines and promote in vitro and in vivo arteriogenesis through paracrine mechanisms. Circ. Res. 2004, 94, 678-685. [CrossRef] [PubMed]

101. Gyongyosi, M.; Posa, A.; Pavo, N.; Hemetsberger, R.; Kvakan, H.; Steiner-Boker, S.; Petrasi, Z.; Manczur, F.; Pavo, I.J.; Edes, I.F.; et al. Differential effect of ischaemic preconditioning on mobilisation and recruitment of haematopoietic and mesenchymal stem cells in porcine myocardial ischaemia-reperfusion. Thromb. Haemost. 2010, 104, 376-384. [CrossRef] [PubMed]

102. Potier, E.; Ferreira, E.; Andriamanalijaona, R.; Pujol, J.P.; Oudina, K.; Logeart-Avramoglou, D.; Petite, H. Hypoxia affects mesenchymal stromal cell osteogenic differentiation and angiogenic factor expression. Bone 2007, 40, 1078-1087. [CrossRef] [PubMed]

103. Zacharek, A.; Chen, J.; Cui, X.; Li, A.; Li, Y.; Roberts, C.; Feng, Y.; Gao, Q.; Chopp, M. Angiopoietin1/Tie2 and VEGF/Flk1 induced by MSC treatment amplifies angiogenesis and vascular stabilization after stroke. J. Cereb. Blood Flow Metab. 2007, 27, 1684-1691. [CrossRef] [PubMed]

104. Birnbaum, T.; Roider, J.; Schankin, C.J.; Padovan, C.S.; Schichor, C.; Goldbrunner, R.; Straube, A. Malignant gliomas actively recruit bone marrow stromal cells by secreting angiogenic cytokines. J. Neurooncol. 2007, 83, 241-247. [CrossRef] [PubMed]

105. Birnbaum, T.; Hildebrandt, J.; Nuebling, G.; Sostak, P.; Straube, A. Glioblastoma-dependent differentiation and angiogenic potential of human mesenchymal stem cells in vitro. J. Neurooncol. 2011, 105, 57-65. [CrossRef] [PubMed]

106. Au, P.; Tam, J.; Fukumura, D.; Jain, R.K. Bone marrow-derived mesenchymal stem cells facilitate engineering of long-lasting functional vasculature. Blood 2008, 111, 4551-4558. [CrossRef] [PubMed]

107. Grunert, S.; Jechlinger, M.; Beug, H. Diverse cellular and molecular mechanisms contribute to epithelial plasticity and metastasis. Nat. Rev. Mol. Cell Biol. 2003, 4, 657-665. [CrossRef] [PubMed]

108. Jechlinger, M.; Grunert, S.; Tamir, I.H.; Janda, E.; Ludemann, S.; Waerner, T.; Seither, P.; Weith, A.; Beug, H.; Kraut, N. Expression profiling of epithelial plasticity in tumor progression. Oncogene 2003, 22, 7155-7169. [CrossRef] [PubMed]

109. Cannito, S.; Novo, E.; di Bonzo, L.V.; Busletta, C.; Colombatto, S.; Parola, M. Epithelial-mesenchymal transition: From molecular mechanisms, redox regulation to implications in human health and disease. Antioxid. Redox Signal. 2010, 12, 1383-1430. [CrossRef] [PubMed]

110. Polyak, K.; Weinberg, R.A. Transitions between epithelial and mesenchymal states: Acquisition of malignant and stem cell traits. Nat. Rev. Cancer 2009, 9, 265-273. [CrossRef] [PubMed]

111. Thompson, E.W.; Newgreen, D.F.; Tarin, D. Carcinoma invasion and metastasis: A role for epithelial-mesenchymal transition? Cancer Res. 2005, 65, 5991-5995. [CrossRef] [PubMed]

112. Kong, D.; Wang, Z.; Sarkar, S.H.; Li, Y.; Banerjee, S.; Saliganan, A.; Kim, H.R.; Cher, M.L.; Sarkar, F.H. Platelet-derived growth factor-D overexpression contributes to epithelial-mesenchymal transition of PC3 prostate cancer cells. Stem Cells 2008, 26, 1425-1435. [CrossRef] [PubMed]

113. Kalluri, R.; Weinberg, R.A. The basics of epithelial-mesenchymal transition. J. Clin. Investig. 2009, 119, 1420-1428. [CrossRef] [PubMed]

114. Thiery, J.P. Epithelial-mesenchymal transitions in tumour progression. Nat. Rev. Cancer 2002, 2, $442-454$. [CrossRef] [PubMed]

115. Tse, J.C.; Kalluri, R. Mechanisms of metastasis: Epithelial-to-mesenchymal transition and contribution of tumor microenvironment. J. Cell. Biochem. 2007, 101, 816-829. [CrossRef] [PubMed]

116. Martin, F.T.; Dwyer, R.M.; Kelly, J.; Khan, S.; Murphy, J.M.; Curran, C.; Miller, N.; Hennessy, E.; Dockery, P.; Barry, F.P.; et al. Potential role of mesenchymal stem cells (MSCs) in the breast tumour microenvironment: Stimulation of epithelial to mesenchymal transition (EMT). Breast Cancer Res. Treat. 2010, 124, 317-326. [CrossRef] [PubMed] 
117. Chen, D.; Liu, S.; Ma, H.; Liang, X.; Ma, H.; Yan, X.; Yang, B.; Wei, J.; Liu, X. Paracrine factors from adipose-mesenchymal stem cells enhance metastatic capacity through Wnt signaling pathway in a colon cancer cell co-culture model. Cancer Cell Int. 2015, 15, 42. [PubMed]

118. Strong, A.L.; Ohlstein, J.F.; Biagas, B.A.; Rhodes, L.V.; Pei, D.T.; Tucker, H.A.; Llamas, C.; Bowles, A.C.; Dutreil, M.F.; Zhang, S.; et al. Leptin produced by obese adipose stromal/stem cells enhances proliferation and metastasis of estrogen receptor positive breast cancers. Breast Cancer Res. 2015, 17, 112. [CrossRef] [PubMed]

119. Xue, J.; Zhu, Y.; Sun, Z.; Ji, R.; Zhang, X.; Xu, W.; Yuan, X.; Zhang, B.; Yan, Y.; Yin, L.; et al. Tumorigenic hybrids between mesenchymal stem cells and gastric cancer cells enhanced cancer proliferation, migration and stemness. BMC Cancer 2015, 15, 793. [CrossRef] [PubMed]

120. He, X.; Tsang, T.C.; Pipes, B.L.; Ablin, R.J.; Harris, D.T. A stem cell fusion model of carcinogenesis. J. Exp. Ther. Oncol. 2005, 5, 101-109. [PubMed]

121. Rizvi, A.Z.; Swain, J.R.; Davies, P.S.; Bailey, A.S.; Decker, A.D.; Willenbring, H.; Grompe, M.; Fleming, W.H.; Wong, M.H. Bone marrow-derived cells fuse with normal and transformed intestinal stem cells. Proc. Natl. Acad. Sci. USA 2006, 103, 6321-6325. [CrossRef] [PubMed]

122. Schichor, C.; Albrecht, V.; Korte, B.; Buchner, A.; Riesenberg, R.; Mysliwietz, J.; Paron, I.; Motaln, H.; Turnsek, T.L.; Jurchott, K.; et al. Mesenchymal stem cells and glioma cells form a structural as well as a functional syncytium in vitro. Exp. Neurol. 2012, 234, 208-219. [CrossRef] [PubMed]

123. Xu, M.H.; Gao, X.; Luo, D.; Zhou, X.D.; Xiong, W.; Liu, G.X. EMT and acquisition of stem cell-like properties are involved in spontaneous formation of tumorigenic hybrids between lung cancer and bone marrow-derived mesenchymal stem cells. PLOS ONE 2014, 9. [CrossRef] [PubMed]

124. Li, H.; Feng, Z.; Tsang, T.C.; Tang, T.; Jia, X.; He, X.; Pennington, M.E.; Badowski, M.S.; Liu, A.K.; Chen, D.; et al . Fusion of HepG2 cells with mesenchymal stem cells increases cancer associated and malignant properties: An in vivo metastasis model. Oncol. Rep. 2014, 32, 539-547. [CrossRef] [PubMed]

125. Ricci-Vitiani, L.; Lombardi, D.G.; Pilozzi, E.; Biffoni, M.; Todaro, M.; Peschle, C.; de Maria, R. Identification and expansion of human colon-cancer-initiating cells. Nature 2007, 445, 111-115. [CrossRef] [PubMed]

126. Kakarala, M.; Wicha, M.S. Implications of the cancer stem-cell hypothesis for breast cancer prevention and therapy. J. Clin. Oncol. 2008, 26, 2813-2820. [CrossRef] [PubMed]

127. Liu, S.; Ginestier, C.; Ou, S.J.; Clouthier, S.G.; Patel, S.H.; Monville, F.; Korkaya, H.; Heath, A.; Dutcher, J.; Kleer, C.G.; et al. Breast cancer stem cells are regulated by mesenchymal stem cells through cytokine networks. Cancer Res. 2011, 71, 614-624. [CrossRef] [PubMed]

128. McLean, K.; Gong, Y.; Choi, Y.; Deng, N.; Yang, K.; Bai, S.; Cabrera, L.; Keller, E.; McCauley, L.; Cho, K.R.; et al. Human ovarian carcinoma-associated mesenchymal stem cells regulate cancer stem cells and tumorigenesis via altered BMP production. J. Clin. Investig. 2011, 121, 3206-3219. [CrossRef] [PubMed]

129. Tsukamoto, S.; Honoki, K.; Fujii, H.; Tohma, Y.; Kido, A.; Mori, T.; Tsujiuchi, T.; Tanaka, Y. Mesenchymal stem cells promote tumor engraftment and metastatic colonization in rat osteosarcoma model. Int. J. Oncol. 2012, 40, 163-169. [PubMed]

130. Shinagawa, K.; Kitadai, Y.; Tanaka, M.; Sumida, T.; Kodama, M.; Higashi, Y.; Tanaka, S.; Yasui, W.; Chayama, K. Mesenchymal stem cells enhance growth and metastasis of colon cancer. Int. J. Cancer 2010, 127, 2323-2333. [CrossRef] [PubMed]

131. Yang, X.; Hou, J.; Han, Z.; Wang, Y.; Hao, C.; Wei, L.; Shi, Y. One cell, multiple roles: Contribution of mesenchymal stem cells to tumor development in tumor microenvironment. Cell Biosci. 2013, 3, 5. [CrossRef] [PubMed]

132. Madrigal, M.; Rao, K.S.; Riordan, N.H. A review of therapeutic effects of mesenchymal stem cell secretions and induction of secretory modification by different culture methods. J. Transl. Med. 2014, 12, 260. [CrossRef] [PubMed]

133. Berniakovich, I.; Giorgio, M. Low oxygen tension maintains multipotency, whereas normoxia increases differentiation of mouse bone marrow stromal cells. Int. J. Mol. Sci. 2013, 14, 2119-2134. [CrossRef] [PubMed]

134. Sanchez, C.; Oskowitz, A.; Pochampally, R.R. Epigenetic reprogramming of IGF1 and leptin genes by serum deprivation in multipotential mesenchymal stromal cells. Stem Cells 2009, 27, 375-382. [CrossRef] [PubMed]

135. Hung, S.C.; Pochampally, R.R.; Hsu, S.C.; Sanchez, C.; Chen, S.C.; Spees, J.; Prockop, D.J. Short-term exposure of multipotent stromal cells to low oxygen increases their expression of CX3CR1 and CXCR4 and their engraftment in vivo. PLoS ONE 2007, 2. [CrossRef] [PubMed] 
136. Hung, S.C.; Pochampally, R.R.; Chen, S.C.; Hsu, S.C.; Prockop, D.J. Angiogenic effects of human multipotent stromal cell conditioned medium activate the PI3K-Akt pathway in hypoxic endothelial cells to inhibit apoptosis, increase survival, and stimulate angiogenesis. Stem Cells 2007, 25, 2363-2370. [CrossRef] [PubMed]

137. Efimenko, A.; Starostina, E.; Kalinina, N.; Stolzing, A. Angiogenic properties of aged adipose derived mesenchymal stem cells after hypoxic conditioning. J. Transl. Med. 2011, 9, 10. [CrossRef] [PubMed]

138. Park, J.B.; Lee, J.S.; Cho, B.P.; Rhee, K.J.; Baik, S.K.; Kim, J.; Kang, S.J.; Park, D.J.; Oh, J.E.; Shin, H.C.; et al. Adipose tissue-derived mesenchymal stem cells cultured at high cell density express brain-derived neurotrophic factor and exert neuroprotective effects in a 6-hydroxydopamine rat model of Parkinson's disease. Genes Genom. 2015, 37, 213-221. [CrossRef]

139. Dias, S.; Choy, M.; Alitalo, K.; Rafii, S. Vascular endothelial growth factor (VEGF)-C signaling through FLT-4 (VEGFR-3) mediates leukemic cell proliferation, survival, and resistance to chemotherapy. Blood 2002, 99, 2179-2184. [CrossRef] [PubMed]

140. Dias, S.; Shmelkov, S.V.; Lam, G.; Rafii, S. VEGF 165 promotes survival of leukemic cells by Hsp90-mediated induction of Bcl-2 expression and apoptosis inhibition. Blood 2002, 99, 2532-2540. [CrossRef] [PubMed]

141. Konig, A.; Menzel, T.; Lynen, S.; Wrazel, L.; Rosen, A.; al-Katib, A.; Raveche, E.; Gabrilove, J.L. Basic fibroblast growth factor (bFGF) upregulates the expression of bcl-2 in B cell chronic lymphocytic leukemia cell lines resulting in delaying apoptosis. Leukemia 1997, 11, 258-265. [CrossRef] [PubMed]

142. Brogi, E.; Wu, T.; Namiki, A.; Isner, J.M. Indirect angiogenic cytokines upregulate VEGF and bFGF gene expression in vascular smooth muscle cells, whereas hypoxia upregulates VEGF expression only. Circulation 1994, 90, 649-652. [CrossRef] [PubMed]

143. Burger, J.A.; Tsukada, N.; Burger, M.; Zvaifler, N.J.; Dell'Aquila, M.; Kipps, T.J. Blood-derived nurse-like cells protect chronic lymphocytic leukemia B cells from spontaneous apoptosis through stromal cell-derived factor-1. Blood 2000, 96, 2655-2663. [PubMed]

144. Ohlsson, L.B.; Varas, L.; Kjellman, C.; Edvardsen, K.; Lindvall, M. Mesenchymal progenitor cell-mediated inhibition of tumor growth in vivo and in vitro in gelatin matrix. Exp. Mol. Pathol. 2003, 75, 248-255. [CrossRef] [PubMed]

145. Lu, Y.R.; Yuan, Y.; Wang, X.J.; Wei, L.L.; Chen, Y.N.; Cong, C.; Li, S.F.; Long, D.; Tan, W.D.; Mao, Y.Q.; et al. The growth inhibitory effect of mesenchymal stem cells on tumor cells in vitro and in vivo. Cancer Biol. Ther. 2008, 7, 245-251. [CrossRef] [PubMed]

146. Ryu, H.; Oh, J.E.; Rhee, K.J.; Baik, S.K.; Kim, J.; Kang, S.J.; Sohn, J.H.; Choi, E.; Shin, H.C.; Kim, Y.M.; et al. Adipose tissue-derived mesenchymal stem cells cultured at high density express IFN- $\beta$ and suppress the growth of MCF-7 human breast cancer cells. Cancer Lett. 2014, 352, 220-227. [CrossRef] [PubMed]

147. Du, J.; Zhou, L.; Chen, X.; Yan, S.; Ke, M.; Lu, X.; Wang, Z.; Yu, W.; Xiang, A.P. IFN- $\gamma$-primed human bone marrow mesenchymal stem cells induce tumor cell apoptosis in vitro via tumor necrosis factor-related apoptosis-inducing ligand. Int. J. Biochem. Cell Biol. 2012, 44, 1305-1314. [CrossRef] [PubMed]

148. Secchiero, P.; Zorzet, S.; Tripodo, C.; Corallini, F.; Melloni, E.; Caruso, L.; Bosco, R.; Ingrao, S.; Zavan, B.; Zauli, G. Human bone marrow mesenchymal stem cells display anti-cancer activity in scid mice bearing disseminated non-Hodgkin's lymphoma xenografts. PLoS ONE 2010, 5. [CrossRef] [PubMed]

149. Glennie, S.; Soeiro, I.; Dyson, P.J.; Lam, E.W.; Dazzi, F. Bone marrow mesenchymal stem cells induce division arrest anergy of activated T cells. Blood 2005, 105, 2821-2827. [CrossRef] [PubMed]

150. Aggarwal, S.; Pittenger, M.F. Human mesenchymal stem cells modulate allogeneic immune cell responses. Blood 2005, 105, 1815-1822. [CrossRef] [PubMed]

151. Corcione, A.; Benvenuto, F.; Ferretti, E.; Giunti, D.; Cappiello, V.; Cazzanti, F.; Risso, M.; Gualandi, F.; Mancardi, G.L.; Pistoia, V.; et al. Human mesenchymal stem cells modulate B-cell functions. Blood 2006, 107, 367-372. [CrossRef] [PubMed]

152. Sotiropoulou, P.A.; Perez, S.A.; Gritzapis, A.D.; Baxevanis, C.N.; Papamichail, M. Interactions between human mesenchymal stem cells and natural killer cells. Stem Cells 2006, 24, 74-85. [CrossRef] [PubMed]

153. Ramasamy, R.; Lam, E.W.; Soeiro, I.; Tisato, V.; Bonnet, D.; Dazzi, F. Mesenchymal stem cells inhibit proliferation and apoptosis of tumor cells: Impact on in vivo tumor growth. Leukemia 2007, 21, 304-310. [CrossRef] [PubMed]

154. Engelman, J.A.; Luo, J.; Cantley, L.C. The evolution of phosphatidylinositol 3-kinases as regulators of growth and metabolism. Nat. Rev. Genet. 2006, 7, 606-619. [CrossRef] [PubMed]

155. Cantley, L.C. The phosphoinositide 3-kinase pathway. Science 2002, 296, 1655-1657. [CrossRef] [PubMed] 
156. Altomare, D.A.; Khaled, A.R. Homeostasis and the importance for a balance between AKT/mTOR activity and intracellular signaling. Curr. Med. Chem. 2012, 19, 3748-3762. [CrossRef] [PubMed]

157. Song, M.S.; Salmena, L.; Pandolfi, P.P. The functions and regulation of the PTEN tumour suppressor. Nat. Rev. Mol. Cell Biol. 2012, 13, 283-296. [CrossRef] [PubMed]

158. Jiang, B.H.; Liu, L.Z. PI3K/PTEN signaling in angiogenesis and tumorigenesis. Adv. Cancer Res. 2009, 102, 19-65. [CrossRef] [PubMed]

159. Croce, J.C.; McClay, D.R. Evolution of the Wnt pathways. Methods Mol. Biol. 2008, 469, 3-18. [PubMed]

160. Polakis, P. Wnt signaling and cancer. Genes Dev. 2000, 14, 1837-1851. [CrossRef] [PubMed]

161. Giles, R.H.; van Es, J.H.; Clevers, H. Caught up in a wnt storm: Wnt signaling in cancer. Biochim. Biophys. Acta 2003, 1653, 1-24. [CrossRef]

162. Logan, C.Y.; Nusse, R. The Wnt signaling pathway in development and disease. Annu. Rev. Cell Dev. Biol. 2004, 20, 781-810. [CrossRef] [PubMed]

163. Boerboom, D.; Paquet, M.; Hsieh, M.; Liu, J.; Jamin, S.P.; Behringer, R.R.; Sirois, J.; Taketo, M.M.; Richards, J.S. Misregulated Wnt/ $\beta$-catenin signaling leads to ovarian granulosa cell tumor development. Cancer Res. 2005, 65, 9206-9215. [CrossRef] [PubMed]

164. Monga, S.P. $\beta$-Catenin signaling and roles in liver homeostasis, injury, and tumorigenesis. Gastroenterology 2015, 148, 1294-1310. [CrossRef] [PubMed]

165. Chiurillo, M.A. Role of the Wnt/ $\beta$-catenin pathway in gastric cancer: An in-depth literature review. World J. Exp. Med. 2015, 5, 84-102. [CrossRef] [PubMed]

166. Incassati, A.; Chandramouli, A.; Eelkema, R.; Cowin, P. Key signaling nodes in mammary gland development and cancer: $\beta$-Catenin. Breast Cancer Res. 2010, 12, 213. [CrossRef] [PubMed]

167. Roarty, K.; Rosen, J.M. Wnt and mammary stem cells: Hormones cannot fly wingless. Curr. Opin. Pharmacol. 2010, 10, 643-649. [CrossRef] [PubMed]

168. King, T.D.; Suto, M.J.; Li, Y. The wnt/ $\beta$-catenin signaling pathway: A potential therapeutic target in the treatment of triple negative breast cancer. J. Cell. Biochem. 2012, 113, 13-18. [CrossRef] [PubMed]

169. Gaspar, C.; Fodde, R. APC dosage effects in tumorigenesis and stem cell differentiation. Int. J. Dev. Biol. 2004, 48, 377-386. [CrossRef] [PubMed]

170. Chen, G.; Shukeir, N.; Potti, A.; Sircar, K.; Aprikian, A.; Goltzman, D.; Rabbani, S.A. Up-regulation of Wnt-1 and $\beta$-catenin production in patients with advanced metastatic prostate carcinoma: Potential pathogenetic and prognostic implications. Cancer 2004, 101, 1345-1356. [CrossRef] [PubMed]

171. Moon, R.T.; Kohn, A.D.; De Ferrari, G.V.; Kaykas, A. WNT and $\beta$-catenin signalling: Diseases and therapies. Nat. Rev. Genet. 2004, 5, 691-701. [CrossRef] [PubMed]

172. Loebinger, M.R.; Eddaoudi, A.; Davies, D.; Janes, S.M. Mesenchymal stem cell delivery of TRAIL can eliminate metastatic cancer. Cancer Res. 2009, 69, 4134-4142. [CrossRef] [PubMed]

173. Nakamizo, A.; Marini, F.; Amano, T.; Khan, A.; Studeny, M.; Gumin, J.; Chen, J.; Hentschel, S.; Vecil, G.; Dembinski, J.; et al. Human bone marrow-derived mesenchymal stem cells in the treatment of gliomas. Cancer Res. 2005, 65, 3307-3318. [PubMed]

174. Menon, L.G.; Picinich, S.; Koneru, R.; Gao, H.; Lin, S.Y.; Koneru, M.; Mayer-Kuckuk, P.; Glod, J.; Banerjee, D. Differential gene expression associated with migration of mesenchymal stem cells to conditioned medium from tumor cells or bone marrow cells. Stem Cells 2007, 25, 520-528. [CrossRef] [PubMed]

175. Xin, H.; Kanehira, M.; Mizuguchi, H.; Hayakawa, T.; Kikuchi, T.; Nukiwa, T.; Saijo, Y. Targeted delivery of CX3CL1 to multiple lung tumors by mesenchymal stem cells. Stem Cells 2007, 25, 1618-1626. [CrossRef] [PubMed]

176. Komarova, S.; Kawakami, Y.; Stoff-Khalili, M.A.; Curiel, D.T.; Pereboeva, L. Mesenchymal progenitor cells as cellular vehicles for delivery of oncolytic adenoviruses. Mol. Cancer Ther. 2006, 5, 755-766. [CrossRef] [PubMed]

177. Mendes, S.C.; Robin, C.; Dzierzak, E. Mesenchymal progenitor cells localize within hematopoietic sites throughout ontogeny. Development 2005, 132, 1127-1136. [CrossRef] [PubMed]

178. Sordi, V.; Malosio, M.L.; Marchesi, F.; Mercalli, A.; Melzi, R.; Giordano, T.; Belmonte, N.; Ferrari, G.; Leone, B.E.; Bertuzzi, F.; et al. Bone marrow mesenchymal stem cells express a restricted set of functionally active chemokine receptors capable of promoting migration to pancreatic islets. Blood 2005, 106, 419-427. [CrossRef] [PubMed] 
179. Giordano, A.; Galderisi, U.; Marino, I.R. From the laboratory bench to the patient's bedside: An update on clinical trials with mesenchymal stem cells. J. Cell. Physiol. 2007, 211, 27-35. [CrossRef] [PubMed]

180. Subramanian, A.; Shu-Uin, G.; Kae-Siang, N.; Gauthaman, K.; Biswas, A.; Choolani, M.; Bongso, A.; Chui-Yee, F. Human umbilical cord Wharton's jelly mesenchymal stem cells do not transform to tumor-associated fibroblasts in the presence of breast and ovarian cancer cells unlike bone marrow mesenchymal stem cells. J. Cell. Biochem. 2012, 113, 1886-1895. [CrossRef] [PubMed]

181. Lotfi, R.; Eisenbacher, J.; Solgi, G.; Fuchs, K.; Yildiz, T.; Nienhaus, C.; Rojewski, M.T.; Schrezenmeier, H. Human mesenchymal stem cells respond to native but not oxidized damage associated molecular pattern molecules from necrotic (tumor) material. Eur. J. Immunol. 2011, 41, 2021-2028. [CrossRef] [PubMed]

182. Barbash, I.M.; Chouraqui, P.; Baron, J.; Feinberg, M.S.; Etzion, S.; Tessone, A.; Miller, L.; Guetta, E.; Zipori, D.; Kedes, L.H.; et al. Systemic delivery of bone marrow-derived mesenchymal stem cells to the infarcted myocardium: Feasibility, cell migration, and body distribution. Circulation 2003, 108, 863-868. [CrossRef] [PubMed]

183. Nystedt, J.; Anderson, H.; Tikkanen, J.; Pietila, M.; Hirvonen, T.; Takalo, R.; Heiskanen, A.; Satomaa, T.; Natunen, S.; Lehtonen, S.; et al. Cell surface structures influence lung clearance rate of systemically infused mesenchymal stromal cells. Stem Cells 2013, 31, 317-326. [CrossRef] [PubMed]

184. Di Bonzo, L.V.; Ferrero, I.; Cravanzola, C.; Mareschi, K.; Rustichell, D.; Novo, E.; Sanavio, F.; Cannito, S.; Zamara, E.; Bertero, M.; et al. Human mesenchymal stem cells as a two-edged sword in hepatic regenerative medicine: Engraftment and hepatocyte differentiation versus profibrogenic potential. Gut 2008, 57, $223-231$. [CrossRef] [PubMed]

185. Baertschiger, R.M.; Serre-Beinier, V.; Morel, P.; Bosco, D.; Peyrou, M.; Clement, S.; Sgroi, A.; Kaelin, A.; Buhler, L.H.; Gonelle-Gispert, C. Fibrogenic potential of human multipotent mesenchymal stromal cells in injured liver. PLoS ONE 2009, 4. [CrossRef] [PubMed]

186. Janowski, M.; Lyczek, A.; Engels, C.; Xu, J.; Lukomska, B.; Bulte, J.W.; Walczak, P. Cell size and velocity of injection are major determinants of the safety of intracarotid stem cell transplantation. J. Cereb. Blood Flow Metab. 2013, 33, 921-927. [CrossRef] [PubMed]

187. Schrepfer, S.; Deuse, T.; Reichenspurner, H.; Fischbein, M.P.; Robbins, R.C.; Pelletier, M.P. Stem cell transplantation: The lung barrier. Transplant. Proc. 2007, 39, 573-576. [CrossRef] [PubMed]

188. Studeny, M.; Marini, F.C.; Champlin, R.E.; Zompetta, C.; Fidler, I.J.; Andreeff, M. Bone marrow-derived mesenchymal stem cells as vehicles for interferon-beta delivery into tumors. Cancer Res. 2002, 62, 3603-3608. [PubMed]

189. Ren, C.; Kumar, S.; Chanda, D.; Chen, J.; Mountz, J.D.; Ponnazhagan, S. Therapeutic potential of mesenchymal stem cells producing interferon- $\alpha$ in a mouse melanoma lung metastasis model. Stem Cells 2008, 26, 2332-2338. [CrossRef] [PubMed]

190. Ren, C.; Kumar, S.; Chanda, D.; Kallman, L.; Chen, J.; Mountz, J.D.; Ponnazhagan, S. Cancer gene therapy using mesenchymal stem cells expressing interferon- $\beta$ in a mouse prostate cancer lung metastasis model. Gene Ther. 2008, 15, 1446-1453. [CrossRef] [PubMed]

191. Chen, X.C.; Wang, R.; Zhao, X.; Wei, Y.Q.; Hu, M.; Wang, Y.S.; Zhang, X.W.; Zhang, R.; Zhang, L.; Yao, B.; et al . Prophylaxis against carcinogenesis in three kinds of unestablished tumor models via IL12-gene-engineered MSCs. Carcinogenesis 2006, 27, 2434-2441. [CrossRef] [PubMed]

192. Nakamura, K.; Ito, Y.; Kawano, Y.; Kurozumi, K.; Kobune, M.; Tsuda, H.; Bizen, A.; Honmou, O.; Niitsu, Y.; Hamada, H. Antitumor effect of genetically engineered mesenchymal stem cells in a rat glioma model. Gene Ther. 2004, 11, 1155-1164. [CrossRef] [PubMed]

193. Chen, X.; Lin, X.; Zhao, J.; Shi, W.; Zhang, H.; Wang, Y.; Kan, B.; Du, L.; Wang, B.; Wei, Y.; et al. A tumor-selective biotherapy with prolonged impact on established metastases based on cytokine gene-engineered MSCs. Mol. Ther. 2008, 16, 749-756. [CrossRef] [PubMed]

194. Kidd, S.; Caldwell, L.; Dietrich, M.; Samudio, I.; Spaeth, E.L.; Watson, K.; Shi, Y.; Abbruzzese, J.; Konopleva, M.; Andreeff, M.; et al. Mesenchymal stromal cells alone or expressing interferon-beta suppress pancreatic tumors in vivo, an effect countered by anti-inflammatory treatment. Cytotherapy 2010, 12, 615-625. [CrossRef] [PubMed]

195. Gao, P.; Ding, Q.; Wu, Z.; Jiang, H.; Fang, Z. Therapeutic potential of human mesenchymal stem cells producing IL-12 in a mouse xenograft model of renal cell carcinoma. Cancer Lett. 2010, 290, 157-166. [CrossRef] [PubMed] 
196. Hakkarainen, T.; Sarkioja, M.; Lehenkari, P.; Miettinen, S.; Ylikomi, T.; Suuronen, R.; Desmond, R.A.; Kanerva, A.; Hemminki, A. Human mesenchymal stem cells lack tumor tropism but enhance the antitumor activity of oncolytic adenoviruses in orthotopic lung and breast tumors. Hum. Gene Ther. 2007, 18, 627-641. [CrossRef] [PubMed]

197. Stoff-Khalili, M.A.; Rivera, A.A.; Mathis, J.M.; Banerjee, N.S.; Moon, A.S.; Hess, A.; Rocconi, R.P.; Numnum, T.M.; Everts, M.; Chow, L.T.; et al. Mesenchymal stem cells as a vehicle for targeted delivery of crads to lung metastases of breast carcinoma. Breast Cancer Res. Treat. 2007, 105, 157-167. [CrossRef] [PubMed]

198. Kucerova, L.; Matuskova, M.; Pastorakova, A.; Tyciakova, S.; Jakubikova, J.; Bohovic, R.; Altanerova, V.; Altaner, C. Cytosine deaminase expressing human mesenchymal stem cells mediated tumour regression in melanoma bearing mice. J. Gene Med. 2008, 10, 1071-1082. [CrossRef] [PubMed]

199. Kucerova, L.; Altanerova, V.; Matuskova, M.; Tyciakova, S.; Altaner, C. Adipose tissue-derived human mesenchymal stem cells mediated prodrug cancer gene therapy. Cancer Res. 2007, 67, 6304-6313. [CrossRef] [PubMed]

200. Li, L.; Guan, Y.; Liu, H.; Hao, N.; Liu, T.; Meng, X.; Fu, C.; Li, Y.; Qu, Q.; Zhang, Y.; et al. Silica nanorattle-doxorubicin-anchored mesenchymal stem cells for tumor-tropic therapy. ACS Nano 2011, 5, 7462-7470. [CrossRef] [PubMed]

201. Xiang, H.; Nguyen, C.B.; Kelley, S.K.; Dybdal, N.; Escandon, E. Tissue distribution, stability, and pharmacokinetics of APO2 ligand/tumor necrosis factor-related apoptosis-inducing ligand in human colon carcinoma COLO205 tumor-bearing nude mice. Drug Metab. Dispos. 2004, 32, 1230-1238. [CrossRef] [PubMed]

202. Menon, L.G.; Kelly, K.; Yang, H.W.; Kim, S.K.; Black, P.M.; Carroll, R.S. Human bone marrow-derived mesenchymal stromal cells expressing S-TRAIL as a cellular delivery vehicle for human glioma therapy. Stem Cells 2009, 27, 2320-2330. [CrossRef] [PubMed]

203. Stagg, J.; Lejeune, L.; Paquin, A.; Galipeau, J. Marrow stromal cells for interleukin-2 delivery in cancer immunotherapy. Hum. Gene Ther. 2004, 15, 597-608. [CrossRef] [PubMed]

204. Eliopoulos, N.; Francois, M.; Boivin, M.N.; Martineau, D.; Galipeau, J. Neo-organoid of marrow mesenchymal stromal cells secreting interleukin-12 for breast cancer therapy. Cancer Res. 2008, 68, 4810-4818. [CrossRef] [PubMed]

205. Dembinski, J.L.; Spaeth, E.L.; Fueyo, J.; Gomez-Manzano, C.; Studeny, M.; Andreeff, M.; Marini, F.C. Reduction of nontarget infection and systemic toxicity by targeted delivery of conditionally replicating viruses transported in mesenchymal stem cells. Cancer Gene Ther. 2010, 17, 289-297. [CrossRef] [PubMed]

206. Uchibori, R.; Okada, T.; Ito, T.; Urabe, M.; Mizukami, H.; Kume, A.; Ozawa, K. Retroviral vector-producing mesenchymal stem cells for targeted suicide cancer gene therapy. J. Gene Med. 2009, 11, 373-381. [CrossRef] [PubMed]

207. Matuskova, M.; Hlubinova, K.; Pastorakova, A.; Hunakova, L.; Altanerova, V.; Altaner, C.; Kucerova, L. HSV-tk expressing mesenchymal stem cells exert bystander effect on human glioblastoma cells. Cancer Lett. 2010, 290, 58-67. [CrossRef] [PubMed]

208. Zischek, C.; Niess, H.; Ischenko, I.; Conrad, C.; Huss, R.; Jauch, K.W.; Nelson, P.J.; Bruns, C. Targeting tumor stroma using engineered mesenchymal stem cells reduces the growth of pancreatic carcinoma. Ann. Surg. 2009, 250, 747-753. [CrossRef] [PubMed]

209. Hamada, H.; Kobune, M.; Nakamura, K.; Kawano, Y.; Kato, K.; Honmou, O.; Houkin, K.; Matsunaga, T.; Niitsu, Y. Mesenchymal stem cells (MSC) as therapeutic cytoreagents for gene therapy. Cancer Sci. 2005, 96, 149-156. [CrossRef] [PubMed]

210. Kim, G.; Eom, Y.W.; Baik, S.K.; Shin, Y.; Lim, Y.L.; Kim, M.Y.; Kwon, S.O.; Chang, S.J. Therapeutic effects of mesenchymal stem cells for patients with chronic liver diseases: Systematic review and meta-analysis. J. Korean Med. Sci. 2015, 30, 1405-1415. [CrossRef] [PubMed]

(C) 2015 by the authors; licensee MDPI, Basel, Switzerland. This article is an open access article distributed under the terms and conditions of the Creative Commons by Attribution (CC-BY) license (http://creativecommons.org/licenses/by/4.0/). 